Bundesgesundheitsbl - Gesundheitsforsch Gesundheitsschutz 2006 • 49:1050-1058 DOI 10.1007/s00103-006-0085-6 Online publiziert: 4. Oktober 2006 ๑) Springer Medizin Verlag 2006

B.-M. Kurth · Robert Koch-Institut, Berlin, BRD

\title{
Symposium zur Studie zur Gesundheit von Kindern und Jugendlichen in Deutschland
}

nanziert. Die Untersuchungen wurden von 4 ärztlich geleiteten Untersuchungsteams in insgesamt 167 für die Bundesrepublik repräsentativen Städten und Gemeinden (Sample Points) durchgeführt. Das nach Altersgruppen gestaffelte Untersuchungsprogramm bestand aus einer Befragung von Eltern und ab 11 Jahren auch der Jugendlichen selbst, medizinischen Untersuchungen und Tests, einem computergestützten ärztlichen Elterninterview sowie einer Probennahme von Blut und Urin. $\mathrm{Zu}$ folgenden Themen wurden Daten erhoben: körperliche Beschwerden und Befindlichkeit, akute und chronische Krankheiten, Behinderungen, Gesundheitsrisiken und Unfälle, psychische Gesundheit, Lebensqualität, Schutzfaktoren und personale Ressourcen, Ernährung, Essstörungen und Adipositas, Gesundheitsverhalten und Freizeitaktivitäten, Medikamentenkonsum, Impfstatus, Inanspruchnahme medizinischer Leistungen, Körpermaße, motorische Leistungsfähigkeit, Sehvermögen, Blutdruck, Blut- und Urindiagnostik sowie Schilddrüsengröße (Letzteres finanziert durch das Bundesministerium für Ernährung, Landwirtschaft und Verbraucherschutz; BMELV). Die Teilnehmer wurden zufällig aus den Melderegistern der Einwohnermeldeämter der Studienorte ausgewählt. Die Teilnahmequote lag bei $66,6 \%$ und damit über dem Durchschnitt vergleichbarer Erhebungen. Insgesamt haben 17.641 Kinder und Jugendliche, darunter 8656 Mädchen und 8985 Jungen, teilgenommen. Die Zusammensetzung der endgültigen Stichprobe weist - mit beispielsweise anteilig $17 \%$ von Kindern und Jugendlichen mit Migrationshintergrund und $2 \%$ mit einer amtlich anerkannten Behinderung - eine hohe Repräsentativität für die Wohnbevölkerung in Deutschland auf.

Ergänzt wird die Studie durch 3 zusätzliche Module, die mit separater Finanzierung von kooperierenden Institutionen durchgeführt wurden. In Teilstichproben wurden die Themen „seelische Gesundheit“ (BELLA, 2863 Teilnehmer), „motorische Entwicklung und Kompetenz" (MoMo, 4529 Teilnehmer) und „Umweltbelastungen“" (Kinder-Umwelt-Survey, 1790 Teilnehmer) vertieft behandelt. Das Land Schleswig-Holstein hat zudem die Möglichkeit genutzt, im Rahmen einer landesweiten Stichprobenaufstockung zusätzlich bei 1630 Kindern und Jugendlichen im Alter von 11-17 Jahren Daten zu erheben und damit für diese Altersgruppe repräsentative Aussagen auf BundeslandEbene zu ermöglichen (Schleswig-Holstein-Modul, 1931 Teilnehmer). Ein fünftes Modul, das im Gegensatz zu den anderen Modulen zeitversetzt erst im Januar 2006 startete und im Dezember 2006 beendet sein wird, konzentriert sich auf das Thema „Ernährung“ (EsKiMo).

Eine ausführliche und thematisch breite Darstellung erster Ergebnisse des Kinder- und Jugendgesundheitssurveys wird im Mai 2007 in einem Sonderheft des 
Bundesgesundheitsblatts publiziert. Im Oktober 2008 werden die Daten als Public Use File der Fachöffentlichkeit verfügbar gemacht.

\section{Schlüsselwörter}

Gesundheitssurvey - Kinder - Jugendliche . Stichprobe $\cdot$ Response $\cdot$ Repräsentativität

\section{Overview of facts and figures of the National Health Interview and Examination Survey for Children and Adolescents (KiGGS) P. Kamtsiuris · M. Lange}

From May 2003 till May 2006, the Robert Koch Institute conducted the National Health Interview and Examination Survey for Children and Adolescents (KiGGS). The aim of this nationwide, representative survey was to collect comprehensive data about the health status of children and adolescents in Germany, aged o to 17 years. The survey was financed by the Federal Ministry of Health (BMG) and the Federal Ministry of Education and Research (BMBF). The examinations were carried out by four teams, each lead by a physician. The teams visited 167 communities (sample points), which were representative for Germany. The examination programme was adapted according to age groups and consisted of a parental questionnaire and additionally a questionnaire for adolescents (ages 11 years and older), medical examinations and tests, a computer-based parental interview as well as a collection of blood and urine. Data was collected for the following topics: physical complaints and well-being, acute and chronic diseases, disabilities, health risks and accidents, mental health, quality of life, protective factors and personal resources, nutrition, eating disorders and obesity, health behaviour and leisure-time activities, medication use, vaccination status, use of medical facilities, anthropometry, motor abilities, visual abilities, blood pressure, blood and urine diagnostics as well as thyroid gland size (the latter being financed by the Federal Ministry of Food, Agriculture and Consumer Protection; BMELV).

The participants were randomly chosen from population registries for each sample point. The participation rate was
$66.6 \%$ and was therefore higher than in comparable surveys. Altogether 17,641 children and adolescents participated in the survey, among them 8,656 girls and 8,985 boys. The net sample showed a high representativity for the children and adolescent population of Germany, with $17 \%$ having a migration background and $2 \%$ being registered as disabled for example.

Additionally, the survey has three modules, which were financed respectively by cooperating institutions. In subsamples topics like "mental health" (BELLA; 2,863 participants), "motor fitness and physical activity" (MoMo; 4,529 participants) and "environmental exposures" (German Environmental Survey IV; 1,79o participants) were investigated in more detail. In addition, the Federal State Schleswig-Holstein used the possibility to collect additional data from 1,630 inhabitants aged 11 to 17 years, to enable representative statements about this age group within this Federal State (Schleswig-Holstein Module; 1,931 participants). A fifth module, which started in January 2006 and will be completed in December 2006 investigates dietary behaviour more comprehensively (EsKiMo).

First results of the survey will be presented in more detail in a special edition of the Bundesgesundheitsblatt, May 2007. In October 2008 the data will be available as a public use file.

\section{Keywords}

Health survey · Children · Adolescents . Sample $\cdot$ Response $\cdot$ Representativity

\section{Die Verbreitung von Übergewicht und Adipositas bei Kindern und Jugendlichen}

\section{A. Schaffrath Rosario - B.-M. Kurth}

Übergewicht und Adipositas sind ein wachsendes gesundheitliches Problem, auch in Deutschland, auch bei Kindern und Jugendlichen. Bislang gab es für diese Bevölkerungsgruppe in Deutschland keine repräsentativen und altersspezifischen Aussagen zur Verbreitung des Problems. Einschätzungen beispielsweise aus den Schuleingangsuntersuchungen ließen kaum Schlussfolgerungen für die anderen Altersgruppen zu, regionale Untersuchungen konnten nicht auf die gesamte
Bundesrepublik verallgemeinert werden. Mit den Gewichts- und Größenmessungen im KiGGS liegen erstmalig bundesweit repräsentative Aussagen zur Verbreitung von Übergewicht und Adipositas bei Jungen und Mädchen vor.

Methoden. Im Rahmen von KiGGS wurden die Studienteilnehmer standardisiert gemessen und gewogen. Zur Definition von Übergewicht und Adipositas wurden entsprechend den Empfehlungen der "Arbeitsgemeinschaft Adipositas im Kindes- und Jugendalter" die von KromeyerHauschild vorgelegten Referenzdaten zur Verteilung des Body-Mass-Index (BMI = Körpergewicht in kg/Quadrat der Körpergröße in $\mathrm{m}^{2}$ ) zugrunde gelegt. Als übergewichtig gelten danach Kinder, deren BMI höher liegt als der BMI bei $90 \%$ der Kinder in der jeweils betrachteten Alters- und Geschlechtsgruppe des Referenzkollektivs (9o. Perzentil). Adipositas (Fettleibigkeit) liegt vor, wenn das 97. Perzentil überschritten wird.

Ergebnisse. Insgesamt sind $15 \%$ der Kinder und Jugendlichen von 3-17 Jahren übergewichtig, und $6,3 \%$ leiden unter Adipositas. Der Anteil der Übergewichtigen steigt von $9 \%$ bei den 3- bis 6-Jährigen über $15 \%$ bei den 7 - bis 10-Jährigen bis hin zu $17 \%$ bei den 14- bis 17-Jährigen. Die Verbreitung von Adipositas beträgt bei den 3- bis 6-Jährigen 2,9\% und steigt über $6,4 \%$ bei den 7 - bis 10-Jährigen bis auf $8,5 \%$ bei den 14 - bis 17-Jährigen. Klare Unterschiede zwischen Jungen und Mädchen oder zwischen den alten und neuen Bundesländern sind nicht zu erkennen. Ein höheres Risiko für Übergewicht und Adipositas besteht bei Kindern aus sozial benachteiligten Schichten, bei Kindern mit Migrationshintergrund, bei Kindern, die nicht gestillt wurden, und bei Kindern, deren Eltern ebenfalls übergewichtig sind.

Perspektiven. Wie die einzelnen Faktoren zusammenhängen und welche Komponenten des Lebensstils letztendlich den größten Einfluss auf die Entwicklung von Übergewicht und Adipositas haben könnten, ist Gegenstand der weiteren Auswertung des nun vorliegenden $\mathrm{Da}$ tensatzes. Zudem wird die gesundheits- 
politische Relevanz des Problems noch deutlicher, wenn die Auswirkungen von Adipositas auf Blutdruck, Blutzuckerwerte, Cholesterinspiegel, subjektive Lebensqualität und psychische Befindlichkeit anhand der im KiGGS gesammelten Informationen bewertet werden können.

\section{Schlüsselwörter}

Gesundheitssurvey · Kinder · Jugendliche · Essstörungen - Übergewicht · Adipositas . Soziale Schicht $\cdot$ Migranten

The prevalence of overweight and obese children and adolescents living in Germany

\section{A. Schaffrath Rosario - B.-M. Kurth}

Obesity is an increasing problem: worldwide, for Germany and for children and adolescents. Until now there have been no representative and age-specific assessments of the distribution of obesity in this section of the German population. Data from, for example, examinations at the start of schooling does not aid conclusions for other age groups, and regional surveys cannot be extrapolated across the whole of Germany. So the height and weight measurements gathered by the National Health Interview and Examination Survey for Children and Adolescents (KiGGS) have, for the first time, provided national, representative data about obesity in young people.

Methods. Within the study height and weight of the participants were measured in a standardised way. The terms 'overweight' and 'obese' are defined according to the recommendations of the Arbeitsgemeinschaft Adipositas im Kindes- und Jugendalter (the Working Group for Obesity in Childhood and Adolescence) using the percentiles of the body mass index $(\mathrm{BMI}=$ weight in $\mathrm{kg}$ /height squared in $\mathrm{m}^{2}$ ) of the Kromeyer-Hauschild reference system. The boundary for being overweight is set as the $90^{\text {th }}$ percentile, i.e. the $\mathrm{BMI}$ value exceeded by $10 \%$ of the children of the same age and sex in the reference data set. Thus children with a BMI higher than this value are classified as overweight. They are classified as obese when their BMI exceeds the $97^{\text {th }}$ percentile.
Results. Overall, $15 \%$ of children and adolescents between the ages of 3 and 17 are overweight, and $6.3 \%$ suffer from obesity. The proportion overweight rises from $9 \%$ of 3-6 year olds to $15 \%$ of 7-10 year olds and $17 \%$ of $14-17$ year olds. The prevalence of obesity is $2.9 \%, 6.4 \%$ and $8.5 \%$ for the same groups respectively. No clear differences between boys and girls or between East and West Germany were detected. Children were at a higher risk of being overweight or obese if they had a lower socioeconomic status, had a migration background, had not been breastfed or had parents who were also overweight.

Perspectives. How these factors act together, and which factors are the decisive ones, will be the subject of further research using the KiGGS data. Moreover, the relevance of the problem to public health will become even clearer once the affects of obesity regarding blood pressure, cholesterol, blood sugar, subjective quality of life and psychological problems have been assessed, again using information from KiGGS.

\section{Keywords}

Health survey · Children · Adolescents - Eating disorders · Overweight · Obesity · Socioeconomic status $\cdot$ migrants

\section{Essstörungen H. Hölling · R. Schlack}

$\mathrm{Zu}$ den Essstörungen zählen Anorexia nervosa (Magersucht), Bulimia nervosa (Ess-/Brechsucht), Adipositas (Fettsucht) im Zusammenhang mit sonstigen psychischen Störungen, Binge Eating Disorder (Episoden von Fressanfällen, ohne einer Gewichtszunahme gegenzusteuern) und sonstige atypische Essstörungen. Die Betroffenen unterscheiden sich zum Teil beträchtlich hinsichtlich ihres körperlichen Erscheinungsbildes und der Psychodynamik ihrer Erkrankung. Einflussfaktoren auf Essstörungen sind Geschlecht, Alter und soziale Schicht.

Methoden. Bei der Befragung von insgesamt 7498 Kindern und Jugendlichen im Alter von 11-17 Jahren wurde der SCOFFFragebogen, ein Screeninginstrument zur Identifikation von Verdachtsfällen auf
Essstörungen eingesetzt. Der Fragebogen weist eine hohe Sensitivität für Anorexie und Bulimie, aber auch für atypische Formen von Essstörungen auf, differenziert jedoch nicht zwischen den verschiedenen Essstörungen. Um die Aussagefähigkeit der Daten zu erhärten, wurden weitere Indikatoren für Essstörungen wie BodyMass-Index (BMI) und Körperselbstbild in die Auswertung einbezogen.

Ergebnisse. Insgesamt $21,9 \%$ der befragten Kinder und Jugendlichen wurden mit dem SCOFF-Fragebogen als auffällig bezüglich ihres Essverhaltens identifiziert (Mädchen: 28,9\%, Jungen 15,2\%). Im Altersverlauf nimmt die Prävalenz bei annähernd gleicher Ausgangsbasis bei beiden Geschlechtern von ca. $20 \%$ im Alter von 11 Jahren bei den Mädchen auf $30,1 \%$ im Alter von 17 Jahren stark $\mathrm{zu}$, bei den Jungen hingegen ab (12,8\%). Der Anteil der Auffälligen mit niedrigem sozioökonomischem Status ist mit 27,6\% fast doppelt so hoch wie der in der oberen Sozialschicht (15,5\%). Die als auffällig Klassifizierten weisen höhere Quoten an psychischen Auffälligkeiten und Depressivitätsneigung auf. Sie sind weniger zufrieden mit ihrem Körperselbstbild, rauchen mehr und berichten häufiger über die Erfahrung sexueller Belästigung.

Schlussfolgerungen. Die Ergebnisse unterstreichen die Notwendigkeit, bereits im frühen Jugendalter über die Erkrankung aufzuklären, Betroffene frühzeitig zu erkennen und Hilfsangebote zielgerichtet zu erweitern. Auf wissenschaftlicher Ebene müssen zur differenzierteren Identifikation von Essstörungen, ihren Ursachen und dem Verlauf, beginnend im Kindesund Jugendalter weitere quer- und längsschnittliche Studien folgen. Der Einsatz von spezifischeren Erfassungsmethoden könnte ggf. Anfangsdiagnosen ermöglichen und Einflüsse auf die Entwicklung einzelner Störungen besser herausarbeiten.

\section{Schlüsselwörter}

Anorexia nervosa · Bulimia nervosa $\cdot$ Binge Eating Disorder · Kinder · Jugendliche ·

SCOFF · Essstörungen · Verhaltensauffälligkeiten · Körperselbstbild 


\section{Eating disorders H. Hölling $\cdot$ R. Schlack}

Eating disorders, such as anorexia nervosa, bulimia nervosa, obesity in combination with mental health problems, Binge Eating Disorder (BED; episodes of massive food intake without weight-reducing strategies) and other, atypical kinds, are among the most common health problems encountered in children and adolescents. Those affected vary considerably in their physical appearance and in the psychological nature of their disorder. Determining factors for eating disorders include sex, age and socio-economic status.

Methods. In total 7,498 boys and girls aged 11 to 17 were assessed using the SCOFF questionnaire, which screens for potential cases of eating disorders and has demonstrated high sensitivity towards anorexia nervosa, bulimia nervosa and other forms in general without, however, differentiating between them. To substantiate this data, further indicators such as BMI and self-rated body image were considered.

Results. Overall $21.9 \%$ of children and adolescents in the sample were identified as being at risk (28.9\% of girls and $15.2 \%$ of boys). This prevalence rises from a base of about $20 \%$ for both sexes at the age of 11 to a rate of $30.1 \%$ in 17 year old girls, whereas for boys it declines to $12.8 \%$ by the same age. The rate in those with a low SES (27.6\%) was almost twice as high as in those with a high SES (15.5\%). Children and adolescents classified as at risk had higher rates of both general mental health problems and depressiveness. Collectively they were less satisfied with their self-rated body image, had a significantly higher proportion of smokers and reported more sexual harassment.

Conclusions. The results indicate the need, from early adolescence, for specific health advice on the causes and symptoms of eating disorders, coupled with the early detection of those at risk and wider provision of targeted support. At a scientific level, further studies should be undertaken to build on the work of KiGGS and improve differentiation between the eating disorders affecting children and adoles- cents. In this way, more specific methods will yield more exact diagnoses and reveal determining factors in the development of eating disorders.

\section{Keywords}

Anorexia nervosa $\cdot$ Bulimia nervosa $\cdot$ Binge Eating Disorder - Children · Adolescents . SCOFF · SES · Mental health problems · Body image

\section{Allergische Erkrankungen M. Schlaud $\cdot$ W. Thierfelder}

Allergische Erkrankungen zählen zu den häufigsten Gesundheitsproblemen im Kindes- und Jugendalter. Bisher fehlen in Deutschland jedoch bundesweit repräsentative Daten, die auch Laborbefunde mit einschließen.

Methoden. Im Kinder- und Jugendgesundheitssurvey (KiGGS) wurden Daten zu den allergischen Erkrankungen Heuschnupfen, Neurodermitis und Asthma durch standardisierte ärztliche Befragung des begleitenden Elternteils erhoben. Gefragt wurde danach, ob ein Arzt jemals die Krankheit festgestellt hätte, ob sie in den letzten 12 Monaten (im Folgenden als "aktuell“ bezeichnet) noch auftrat, sowie nach näheren Einzelheiten. Zusätzlich wurden bei Probanden, deren Eltern einer Blutentnahme zugestimmt hatten, spezifische IgE-Antikörper gegen verschiedene verbreitete Allergene bestimmt.

Ergebnisse. Nach den Ergebnissen leiden $16,7 \%$ aller Kinder und Jugendlichen aktuell unter einer allergischen Erkrankung, darunter mehr Jungen (18,0\%) als Mädchen $(15,4 \%)$. Allergische Krankheiten treten mit zunehmendem Alter häufiger auf. Kinder mit Migrationshintergrund sind seltener betroffen (13,0 \% vs. $17,6 \%)$, ebenso Kinder aus sozial schwachen Familien (Unterschicht 13,6\%, Mittelschicht $17,8 \%$, Oberschicht 18,9\%). Bei Kindern mit mehreren älteren Geschwistern oder mit frühem engen Kontakt zu anderen Kindern in Betreuungseinrichtungen treten allergische Erkrankungen weniger häufig auf. Leiden bereits die Eltern unter Allergien, ist das Allergierisiko für die Kinder mehr als verdoppelt. In Ostdeutschland sind allergische Erkran- kungen nicht weniger verbreitet als unter Kindern in Westdeutschland. Unterschiede zwischen Land und Stadt sind kaum vorhanden. Heuschnupfen wurde bei $10,7 \%$ aller Probanden schon einmal festgestellt, aktuell sind 8,9\% betroffen, davon mehr Jungen (10,3\%) als Mädchen $(7,5 \%)$. Mit steigendem Alter nimmt die Verbreitung des Heuschnupfens von unter $1 \%$ auf über $15 \%$ zu. 13,2 \% aller Kinder hatten jemals eine Neurodermitis, 7,7\% leiden aktuell darunter. Mädchen und Jungen sind etwa gleich häufig betroffen. Mit zunehmendem Alter nimmt die Neurodermitis tendenziell eher ab. Asthma wurde bei 4,7\% aller Kinder jemals festgestellt, aktuell sind 3,0 \% davon betroffen, davon mehr Jungen (3,5\%) als Mädchen (2,5\%). Je städtischer eine Region strukturiert ist, desto häufiger ist Asthma (ländlich 2,3\%; großstädtisch 3,6\%).

Bei 40,8\% zeigt die Blutuntersuchung eine Sensibilisierung gegen mindestens ein Allergen. Gegen Stoffe, die eingeatmet werden (Pollen, Tierhaare, Hausstaubmilben), sind $37,2 \%$ sensibilisiert, gegenüber Nahrungsmitteln 20,2\%. Jungen sind mit 45,0 \% häufiger sensibilisiert als Mädchen $(36,4 \%)$. Mit zunehmendem Alter und mit besserer sozialer Situation steigt der Anteil Sensibilisierter stetig an. Kinder mit Migrationshintergrund sind etwas weniger häufig sensibilisiert. Zwischen Ost- und Westdeutschland und Stadt und Land liegen praktisch keine Unterschiede vor.

Schlussfolgerungen. Die beobachteten Unterschiede in der Verteilung allergischer Erkrankungen und Sensibilisierungen zeigen, dass neben einer erblichen Komponente auch der Lebensstil eine möglicherweise ursächliche Rolle spielt. Sie stützen die „Hygienehypothese“, nach der ein geringer Kontakt zu Krankheitserregern und anderen Allergenen mit einem erhöhten Risiko für spätere Allergien verbunden ist.

\section{Schlüsselwörter}

Gesundheitssurvey · Kinder · Jugendliche · Allergie - Neurodermitis · Heuschnupfen . Asthma $\cdot$ Sensibilisierung 


\section{Allergic Diseases M. Schlaud $\cdot$ W. Thierfelder}

Allergic diseases are among the most commonly encountered health problems in children and adolescents. Until now, Germany has been without national, representative data that include laboratory results.

Methods. In the National Health Interview and Examination Survey for Children and Adolescents (KiGGS), data on the allergic diseases hay fever, atopic dermatitis and asthma were obtained using standardised interviews for parents conducted by trained doctors. Parents were asked whether their child had ever been diagnosed with one of these diseases by a doctor, whether the problem had been evident in the previous 12 months (termed 'current' below), and for further details on the condition. Blood samples were also taken, with parental consent, and tested for specific IgE antibodies against a variety of common antigens.

Results. On the basis of our data, $16.7 \%$ suffered from a current allergic disease, with more boys (18.0\%) affected than girls (15.4\%). The incidence of allergic diseases increased with age. Children from migrant families were less likely to be affected (13.0\% against $17.6 \%$ in general), in common with children from deprived families (below average status $13.6 \%$, average $17.8 \%$, above average $18.9 \%$ ). Allergic diseases were less frequent in children who had several older siblings or had been in close contact with other children in daycare facilities early in life. If their parents had allergies, the risk for children was more than doubled. In East Germany, allergic diseases were not less common than in West Germany. Differences between rural and urban areas were negligible.

Hay fever was diagnosed in $10.7 \%$ of study subjects at some point, with $8.9 \%$ currently affected, of whom more were boys (10.3\%) than girls (7.5\%). The prevalence of current hay fever increased with age from below $1 \%$ to more than $15 \%$. Atopic dermatitis was diagnosed in $13.2 \%$ at some point, with $7.7 \%$ currently affected (roughly equally according to sex). Current atopic dermatitis tended to decrease with age. Asthma was diagnosed in $4.7 \%$ of children and adolescents at some point and $3.0 \%$ were currently affected, of whom, again, more were boys (3.5\%) than girls $(2.5 \%)$. The prevalence was slightly higher in urban (3.6\%) than in rural areas $(2.3 \%)$.

The blood tests revealed an atopic sensitisation to at least one common allergen in $40.8 \%$ of children/adolescents. Sensitisation to inhalative antigens (e.g. pollen, animal hair, dust mites) was $37.2 \%$, compared to $20.2 \%$ for food allergens. Boys were more frequently (45.0\%) sensitised than girls $(36.4 \%)$. As age and social status rose, there was a continuous increase in the prevalence of atopic sensitisations. Children from migrant families were slightly less affected, and there was virtually no difference between East and West Germany or rural and urban areas.

Conclusions. The distribution of allergic diseases and sensitisations observed suggests that, aside from a hereditary component, lifestyle may be an important causal factor. Our findings accord with the 'hygiene hypothesis', which claims that reduced exposure to pathogenic germs or other antigens may increase the risk of allergies later in life.

\section{Keywords}

Health examination survey - Children . Adolescents · Allergies - Atopic dermatitis . Hay fever - Asthma · Atopic sensitisation

\section{Schilddrüsengröße und Jodver- sorgung in Deutschland \\ M. Thamm • U. Ellert}

Die häufigste Ursache für eine Schilddrüsenvergrößerung (Struma, Kropf) ist Jodmangel. Deutschland gilt allgemein noch immer als Jodmangelgebiet.

Methoden. Im Rahmen der ärztlichen Untersuchung wurde bei über 11.000 Kindern und Jugendlichen zwischen 6 und 17 Jahren mittels Ultraschalluntersuchung die Größe der Schilddrüse gemessen. Diese gilt als sehr sensibles Maß für die Jodversorgung beim einzelnen Kind. Zur Beurteilung der Jodversorgung auf Bevölkerungsebene wurde nach internationalen Empfehlungen zusätzlich die Jodausschei- dung im Spontanurin bestimmt. Hierzu liegen Messergebnisse von ca. 14.00o Studienteilnehmern vor.

Ergebnisse. Insgesamt 2,4\% der untersuchten Kinder überschreiten den bislang von der WHO empfohlenen Grenzwert für das Schilddrüsenvolumen. Legt man die wesentlich strikteren, aktuell von einer Arbeitsgruppe der WHO (WHO/NHD Iodine Deficiency Study Group, 2004) vorgelegten Grenzwerte zugrunde, so zeigt sich bei rund einem Drittel der 6bis 17 -Jährigen eine überwiegend leichte Vergrößerung der Schilddrüse. Die Häufigkeit einer Schilddrüsenvergrößerung nimmt mit dem Alter zu, und Mädchen sind häufiger betroffen als Jungen. Ein Zusammenhang mit der sozialen Schicht, dem Migrantenstatus oder Ost-WestUnterschiede können nicht festgestellt werden. Eine leichte Vergrößerung der Schilddrüse hat für sich genommen noch keinen Krankheitswert, sie zeigt aber, dass die Jodversorgung noch nicht optimal ist.

In Übereinstimmung dazu liegt die Jodausscheidung im Urin am unteren Ende einer von der WHO angegebenen Spanne von 100-200 $\mu \mathrm{g} / \mathrm{L}$ für eine optimale Jodaufnahme. Sie beträgt im Mittel (Median) $117 \mu \mathrm{g} / \mathrm{L}$ mit nur geringen Geschlechterunterschieden.

Schlussfolgerungen. Nach den Ergebnissen zur Jodausscheidung im Urin ist Deutschland derzeit kein ausgesprochenes Jodmangelgebiet. Die Anwendung sehr strenger Referenzwerte für das Schilddrüsenvolumen zeigt jedoch noch ein Potenzial für weitere Verbesserungen auf.

\section{Schlüsselwörter}

Gesundheitssurvey · Kinder · Jugendliche .

Jod.Struma $\cdot$ Jodmangel

\section{Thyroid Volume and lodine Supply in Germany}

M. Thamm·U. Ellert

Iodine deficiency is the leading cause of thyroid gland enlargement (goitre). Germany is still widely regarded as an endemically iodine-deficient area.

Methods. As part of a standardised medical examination, thyroid volume was 
measured by ultrasound in more than 11,000 children and adolescents between 6 and 17 years of age. This method is considered to be a very sensitive measure of individual iodine supply. In addition, to assess iodine supply at the population level in accordance with international recommendations, urinary iodine excretion was measured in spot urine samples. This data was complete for approximately 14,000 study participants.

Results. Overall, $2.4 \%$ of children examined exceeded the thyroid volume limit recommended by the WHO to date. Applying the considerably more stringent limit currently advised by a WHO working group (WHO/NHD Iodine Deficiency Study Group, 2004), a predominantly slight enlargement of the thyroid gland was observed in every third participant between 6 and 17 years of age. The frequency of thyroid gland enlargement increased with age and girls were more commonly affected than boys. No correlation with socio-economic status, migration status or East-West differences could be observed. Taken by itself, such a slight enlargement has no clinical significance; instead it shows that the iodine supply is still suboptimal. This agrees with the observed distribution of urinary iodine excretion which was at the lower end of a range of $100-200 \mu \mathrm{g} / \mathrm{l}$, indicating optimal iodine intake according to WHO criteria. Median iodine excretion was $117 \mu \mathrm{g} / \mathrm{l}$, with only minor differences between the sexes.

Conclusions. Based on the results for urinary iodine excretion, Germany is not at present an explicit area of iodine deficiency. The application of very strict reference values to ultrasound measures of thyroid gland volume shows, however, the potential for further improvement.

\section{Keywords}

Health examination survey - Children .

Adolescents · lodine · Struma · lodine deficiency
Sport und Bewegung bei Kindern und Jugendlichen in Deutschland T. Lampert · A. Starker · G. B. M. Mensink

Regelmäßige körperliche Aktivität hat in jedem Alter einen positiven Einfluss auf die Gesundheit und das Wohlbefinden. Sport- und bewegungsfördernde Maßnahmen sind deshalb ein fester Bestandteil von Public Health in Deutschland. Mit dem Kinder- und Jugendgesundheitssurvey (KiGGS) steht nun eine bundesweit repräsentative Datenbasis zur Verfügung, die eine umfassende Analyse des Bewegungsverhaltens in der heranwachsenden Generation erlaubt und damit die Planung und Umsetzung gesundheitspolitischer Interventionen unterstützt.

Methoden. Die ersten Auswertungen zum Bewegungsverhalten von Kindern und Jugendlichen basieren auf Daten des KiGGS-Kernsurveys $(n=17.641)$, die mit auf das jeweilige Alter abgestimmten Instrumenten erhoben wurden. Bei Kindern im Alter von 3-10 Jahren wurden die Eltern gefragt, wie häufig ihre Kinder im Freien spielen und wie häufig sie Sport ausüben. Für Jugendliche im Alter von 11-17 Jahren kann auf Selbstangaben zur körperlichen Aktivität in der Freizeit und körperlichen Leistungsfähigkeit zurückgegriffen werden. Die Daten wurden nach Geschlecht, Migrationshintergrund und Sozialstatus getrennt ausgewertet.

Ergebnisse. Ein Großteil der Kinder im Alter von 3-10 Jahren bewegt sich regelmäßig: $77 \%$ spielen fast täglich im Freien, und $52 \%$ machen wenigstens einmal in der Woche Sport. Zwischen Jungen und Mädchen zeigen sich in dieser Hinsicht keine bedeutsamen Unterschiede. Kinder aus Migrantenfamilien und mit niedrigem Sozialstatus sind weitaus weniger aktiv. Beispielsweise ist die Chance der regelmäßigen sportlichen Betätigung in diesen Gruppen um den Faktor 2-3 verringert.

Von den Jugendlichen im Alter von 11-17 Jahren sind $84 \%$ mindestens einmal in der Woche in der Freizeit so aktiv, dass sie dabei ins Schwitzen oder außer Atem geraten. Rund $23 \%$ erreichen sogar fast jeden Tag dieses Aktivitätsniveau. Die eigene körperliche Leistungsfähigkeit wird von $66 \%$ der Jugendlichen als sehr gut oder gut beurteilt. Im Jugendalter treten anders als im Kindesalter deutliche geschlechtsspezifische Unterschiede im Bewegungsverhalten zutage: Mädchen sind seltener in ihrer Freizeit aktiv und schätzen ihre körperliche Leistungsfähigkeit schlechter ein. Besonders deutlich zeigt sich dies bei Mädchen aus Migrantenfamilien und mit niedrigem Sozialstatus.

Schlussfolgerungen. Die Ergebnisse des Kinder- und Jugendgesundheitssurveys deuten darauf hin, dass die meisten Kinder und Jugendlichen in Deutschland körperlich und sportlich aktiv sind. Zugleich weisen sie aber auf latente Potenziale für die Prävention und Gesundheitsförderung im Kindes- und Jugendalter hin. Die geschlechts-, migrations- und schichtspezifischen Unterschiede im Bewegungsverhalten der Heranwachsenden zeigen mögliche Ansatzpunkte für gezielte Interventionen auf.

\section{Schlüsselwörter}

Sport · Bewegung · Körperliche Aktivität ·

Körperliche Leistungsfähigkeit · Gesundheitssurvey · Kinder · Jugendliche

\section{Sports participation and physical activity among children and adolescents in Germany \\ T. Lampert · A. Starker • G. B. M. Mensink}

Regular physical activity has a positive impact on health and well-being at all ages. Measures promoting sport and other physical activities are therefore an established part of public health policy in Germany. The National Health Interview and Examination Survey for Children and Adolescents (KiGGS) has provided a national, representative database which permits to comprehensively analyse the physical activity of young people. This supports the planning and management of policy interventions.

Methods. The first analyses of children and adolescents physical activity were performed with data of the core survey of KiGGS $(n=17,641)$, assessed with age specific instruments. Parents of children aged 3-10 were asked how often their children 
played outdoors or participated in sports. Adolescents (ages 11-17) were also asked about their physical activities during leisure time and their physical fitness. The data was analysed by sex, migration and socioeconomic status (SES).

Results. The majority of children aged 3-10 are active regularly: $77 \%$ play outdoors almost every day and $52 \%$ play sports at least once a week. No essential differences are observed between boys and girls. Exceptions are boys and especially girls from migrant families and those with a low SES, who tend to be insufficiently active. For instance, children from these groups are about 2 to 3 times less likely to regularly play sports.

Among adolescents (11-17 years), 84\% take part at least once a week in activities that cause them to sweat or become out of breath. Around $23 \%$ take part in such activities almost every day. About $66 \%$ of adolescents rate their physical fitness as good or very good. In contrast to children, substantial differences in physical activity between sexes are seen among adolescents: girls are less often physical active during leisure time and have a lower rating of their fitness level. This is particularly evident among girls from migrant families and those with a low SES.

Conclusions. The results from KiGGS suggest most children and adolescents in Germany are physically active and take part in sports. Nevertheless, there is room for improvement in activity levels if the health of young people is to be safeguarded. Differences in activity behaviour specific to sex, ethnicity and SES indicate potential avenues for future health policy.

\section{Keywords}

Sport - Movement - Physical activity · Fitness . Health survey · Children · Adolescents
Motorik-Modul: Motorische

Leistungsfähigkeit und körperlich-

sportliche Aktivität von Kindern

und Jugendlichen

K. Bös · J. Oberger · E. Opper ·

N. Romahn $\cdot$ M. Wagner $\cdot$ A. Worth

In den Jahren 2003-2006 wurden im Rahmen des Motorik-Moduls, das vom Bundesministerium für Familie, Senioren, Frauen und Jugend (BMFSFJ) gefördert wird, bundesweit repräsentativ 4529 Kinder und Jugendliche zwischen 4 und 17 Jahren hinsichtlich ihrer motorischen Leistungsfähigkeit und körperlich-sportlichen Aktivität untersucht. Dies erfolgte anhand von 11 Testitems zur Ausdauer, Kraft, Koordination und Beweglichkeit und einem Aktivitätsfragebogen.

Ergebnisse. Erste Ergebnisse zeigen, dass $95 \%$ der 4- bis 17-Jährigen im Befragungszeitraum aktiv sind, davon $22 \%$ täglich. Im Durchschnitt sind dies 4 Tage pro Woche für insgesamt 6 Stunden. Insgesamt sind $58 \%$ Mitglied in einem Sportverein. Einem Anstieg der Mitgliedszahlen im Grundschulalter folgt eine hohe Fluktuation im weiteren Verlauf der Adoleszenz. Die Intensität der Aktivität ist im Vereinssport am höchsten.

Im Bereich der Motorik zeigt sich, dass über ein Drittel der Kinder und Jugendlichen nicht in der Lage ist, 2 oder mehr Schritte auf einem $3 \mathrm{~cm}$ breiten Balken rückwärts zu balancieren. Bei der Rumpfbeuge erreichen $43 \%$ nicht das Fußsohlenniveau. Die Ergebnisse im Standweitsprung deuten einen Rückgang der Kraftfähigkeit um $14 \%$ seit 1976 an.

Schlussfolgerungen. Die aufgezeigten Ergebnisse unterstreichen die Notwendigkeit gezielter Interventionen. Hierfür bedarf es weiterer Analysen, vor allem der Zusammenhänge zwischen Motorik, Aktivität und Gesundheit.

\section{Schlüsselwörter}

Motorische Leistungsfähigkeit · Körperlichsportliche Aktivität · Kinder · Jugendliche · Motoriktests
The module "Motorik“: Motor Fitness and physical activity of children and young people K. Bös · J. Oberger · E. Opper · N. Romahn $\cdot$ M. Wagner $\cdot$ A. Worth

Between 2003 and 2006, as part of the Motorik module, supported by the Federal Ministry for Family Affairs, Senior Citizens, Women and Youth (BMFSFJ) a representative cross-national sample of 4,529 children and young people aged 4 to 17 was investigated for their motor fitness and physical activity. Participants' motor fitness was examined using eleven tests measuring cardio-respiratory fitness, strength, coordination and mobility. Physical activity was assessed using a questionnaire.

Results. Early results show that $95 \%$ of the participants are active during the questioning period, $22 \%$ citing a daily activity. On average, they took part in sporting activities four times a week for approximately 6 hours in total. Overall $58 \%$ were members of sports clubs. Membership increases between the ages of 6 and 10 before dropping back for 11-17 year old.

Concerning motor fitness, it was found that that more than a third of the participants were not able to balance while taking two or more steps backwards in a $3 \mathrm{~cm}$ wide bar. On the trunk bend, $43 \%$ could not reach the level of their soles. The measurement of strengths by means of a standing long jump enabled comparison with data from 1976, and showed a deterioration of $14 \%$ over this period.

Conclusions. The findings emphasize the necessity of specific interventions. For this purpose further analyses especially of the association between motor fitness, physical activity and health are needed.

\section{Keywords}

Motor fitness - Physical activity - Children .

Adolescents - Testing of motor fitness

Kinder-Umwelt-Survey (KUS)

M. Kolossa-Gehring · W. Babisch •

R. Szewzyk · D. Ullrich

Methoden. Der Kinder-Umwelt-Survey (KUS) ist ein Modul des KiGGS und wird 
vom Umweltbundesamt durchgeführt. Bei 1790 Kindern im Alter von 3-14 Jahren wurden Umweltbelastungen durch chemische Schadstoffe, Schimmelpilze und Lärm erfasst. Dazu wurden Blut-, Urin-, Innenraumluft-, Hausstaub- und Trinkwasserproben untersucht sowie ein Screening-Hörtest und Befragungen $\mathrm{zu}$ expositionsbeeinflussenden Faktoren durchgeführt.

Ergebnis. Bereits 1990/92 hatte das Umweltbundesamt im 2. Umwelt-Survey Kinder in die Untersuchungen zur Umweltbelastung einbezogen. Daher können nun Aussagen zu einem zeitlichen Trend der Umweltbelastungen bei Kindern getroffen werden. Die Blei-, Quecksilber-, PAH- und PCP-Belastungen haben seit 1990/92 deutlich abgenommen, was den Erfolg umwelt- und gesundheitspolitischer Maßnahmen belegt.

Nicht abgenommen hat hingegen die Belastung der Kinder durch das Passivrauchen. Noch immer leben ca. 50 \% der Kinder in Haushalten mit mindestens einem Raucher. Die Cotiningehalte im Urin deuten darauf hin, dass die Belastung über das Passivrauchen sogar zugenommen hat. In fast der Hälfte der Haushalte, in denen täglich geraucht wird und in denen Kinder leben, wird zudem der zukünftige EU-Grenzwert für Benzol in der Außenluft überschritten.

Bei den Auswertungen des KUS werden auch Zusammenhänge zwischen Umweltbelastungen und gesundheitlichen Wirkungen untersucht. Es zeigt sich, dass ca. $10 \%$ der Kinder gegenüber mindestens einem der im KUS untersuchten Schimmelpilze sensibilisiert sind. Im KUS wird auch das Vorkommen von Sensibilisierungen gegenüber Schimmelpilzen erfasst, die hauptsächlich im Innenraum vorkommen und bisher in routinemäßig eingesetzten Allergietests nicht enthalten sind. Im Hörtest wiesen ca. $13 \%$ der Kinder bei wenigstens einer Testfrequenz einen Hörverlust von mehr als $20 \mathrm{~dB}$ und $2,4 \%$ von mehr als $30 \mathrm{~dB}$ auf. Freizeitlärm kann eine der Ursachen für Hörverlust sein.

Danksagung. Das Projekt wurde mit Mitteln des Bundesministeriums für Umwelt, Naturschutz und Reaktorsicherheit sowie mit Mitteln des Bundesministeriums für Bildung und Forschung (DLR) gefördert. Die Feldarbeit für den Kinder-UmweltSurvey wurde vom Robert Koch-Institut durchgeführt.

\section{Schlüsselwörter}

Kinder-Umwelt-Survey KUS · Blei · Quecksilber - Cotinin - Benzol · PAH · PCP · Schimmelpilze $\cdot$ Innenraum $\cdot$ Hörverlust

\section{German Environmental Survey 2003-06 (GerES IV) \\ M. Kolossa-Gehring · W. Babisch • R. Szewzyk D. Ullrich}

Methods. GerES IV is a module of KiGGS undertaken by the Federal Environment Agency. Exposure to chemical pollutants, mould spores and noise was examined using a representative sample of 1,790 children aged between 3 and 14 . This involved the analysis of blood, urine, house dust and drinking water samples, a screening audiometry and a questionnaire identifying factors relevant to exposure.

Results. Because the Federal Environment Agency had already included children in GerES II (1990-92) subsequent trends in exposure levels can be identified. Exposure to lead, mercury, PAH and PCP has decreased markedly as a result of environmental and health policies.

Exposure to second-hand smoke did not decrease, however. In both surveys around $50 \%$ of children were living in households with at least one smoker. Urinary cotinine levels suggest exposure to second-hand smoke may even have increased. In almost half the households in which smoking occurred daily the future EU limit for benzene in outdoor air was exceeded in the indoor air.

GerES IV will continue to examine links between environmental conditions and health. Around $10 \%$ of children have been shown to be sensitive to at least one of the mould spores analysed. Of the spores included in GerES, most are principally encountered in an indoor environment and are not covered by routine allergy screening tests. In the hearing test, around $13 \%$ of children showed a loss of more than $20 \mathrm{~dB}$, and $2.4 \%$ more than $30 \mathrm{~dB}$, in at least one of the frequencies measured.
Noise from leisure activities is one potential cause of this hearing impairment.

Acknowledgement. The financial support of the Federal Ministries for the Environment, Nature Conservation and Nuclear Safety and of Education and Research is gratefully acknowledged. Field work during GerES IV was carried out by the Robert Koch Institute, Berlin.

\section{Keywords}

Health and environmental survey - ChildrenGerES · Lead · Mercury · Cotinine · Benzene · $\mathrm{PAH} \cdot \mathrm{PCP} \cdot \mathrm{Mould} \cdot$ Indoor environment . Hearing impairment

\section{Modul Psychische Gesundheit (BELLA-Studie) \\ U. Ravens-Sieberer $\cdot$ N. Wille · S. Bettge $\cdot$ M. Erhart}

Das Modul „Psychische Gesundheit“ zum bundesweiten Kinder- und Jugendgesundheitssurvey des Robert Koch-Instituts besteht aus einer Befragung zum seelischen Wohlbefinden und Verhalten, der sog. BELLA-Studie, die vom Stifterverband für die Deutsche Wissenschaft gefördert wird und das Auftreten allgemeiner sowie spezifischer psychischer Auffälligkeit unter Kindern und Jugendlichen in Deutschland beobachtet.

Methoden. In der BELLA-Studie wurden 2863 Familien mit Kindern im Alter von 7-17 Jahren, die an KiGGS teilgenommen haben, vertiefend telefonisch mit einem standardisierten computerassistierten Telefoninterview (CATI) und einer direkt anschließenden postalischen schriftlichen Befragung befragt.

Die Verbreitung psychischer Auffälligkeiten wurde anhand der Angaben im Strengths and Difficulties Questionnaire (SDQ; Goodman 1997) und weiterer standardisierter Screeningverfahren ermittelt.

Ergebnisse. Bei ca. $22 \%$ der untersuchten Kinder und Jugendlichen liegen Hinweise auf eine psychische Auffälligkeit vor, wobei ca. $10 \%$ aller Kinder und Jugendlichen als im engen Sinn psychisch auffällig beurteilt werden müssen. Unter den spezifischen psychischen Auffälligkeiten treten 
Störungen des Sozialverhaltens (10\%), Ängste (7,6\%) und Depressionen (5,4\%) am häufigsten auf. Bei den vermuteten Risikofaktoren erweisen sich vor allem ein ungünstiges Familienklima mit vielen Konflikten sowie ein niedriger sozioökonomischer Status als negative Einflussgrößen, die mit einer bis zu 4 fach erhöhten Wahrscheinlichkeit für psychische Auffälligkeit einhergehen.

Bei einem kumulierten Auftreten mehrerer Risikofaktoren ist ein starker Anstieg der Häufigkeit psychischer Auffälligkeiten (bis zu einem Anteil von 50\% in Hochrisikogruppen) zu verzeichnen. Personale, familiäre und soziale Ressourcen sind hingegen bei psychisch unauffälligen Kindern und Jugendlichen stärker ausgeprägt. Die gesundheitsbezogene Lebensqualität psychisch auffälliger Kinder und Jugendlicher ist in allen Bereichen deutlich eingeschränkt. Längst nicht alle Kinder und Jugendlichen, die psychische Auffälligkeiten aufweisen, befinden sich in entsprechender Behandlung.

Schlussfolgerungen. Die BELLA-Studie zeigt, dass es für die Identifikation von $\mathrm{Ri}$ sikogruppen nicht nur von Bedeutung ist, die bekannten Risikofaktoren für die psychische und subjektive Gesundheit von Kindern und Jugendlichen zu betrachten. Vielmehr müssen auch die vorhandenen personalen, familiären und sozialen Ressourcen einbezogen werden. Die Stärkung der personalen und familiären Ressourcen von Kindern und Jugendlichen sollte wesentliches Ziel von Prävention und Intervention sein.

\section{Schlüsselwörter}

Psychische Gesundheit · Kinder · Jugendliche

· Schutzfaktoren · Risikofaktoren

\section{Mental Health Module (BELLA Study)}

\section{U. Ravens-Sieberer · N. Wille ·}

S. Bettge $\cdot$ M. Erhart

The "Mental Health" module of the National Health Interview and Examination Survey for Children and Adolescents (KiGGS) carried out by the Robert Koch Institute is an examination of emotional wellbeing and behaviour. This so-called BELLA Study, sponsored by the Stifterver- band für die Deutsche Wissenschaft (Association of Donors for German Science), observes the occurrence of both general and specific mental health problems in children and adolescents in Germany.

Methods. In the BELLA Study, 2,863 families with children between the ages of 7 and 17 years, who had taken part in KiGGS, were interviewed over the telephone using a standardised computer-assisted telephone interview (CATI) immediately followed by a postal survey.

The prevalence of mental health problems was determined using the responses to the Strengths and Difficulties Questionnaire (SDQ; Goodman, 1997) and further standardised screening measures.

Results. Approx. $22 \%$ of the children and adolescents studied show signs of mental health problems, whereby about $10 \%$ of all children and adolescents achieve scores which are in the abnormal range. Among the specific psychiatric disorders, anxiety $(7.6 \%)$, conduct disorder (10\%) and depression (5.4\%) are the most common. Among the assumed risk factors, an adverse family climate with many conflicts and low socio-economic status stand out particularly as negative contributors and are associated with up to a 4 -fold increase in the probability of mental health problems.

When several risk factors occur simultaneously, a high increase in the prevalence of mental health problems is observed (constituting up to $50 \%$ in highrisk groups). Conversely, positive individual, family and social resources are more pronounced in children and adolescents without signs of mental health problems. The health-related quality of life of children and adolescents who are conspicuous in terms of their emotional well-being and behaviour is distinctly impaired in all areas. Far from all children and adolescents displaying mental health problems are receiving the appropriate treatment.

Conclusions. The BELLA Study shows that in order to identify high-risk groups, it is not only important to look at the usual risk factors for the mental and subjective health of children and adolescents, but also to assess the existing individual, family and social resources. Strengthening the individual and family resources of children and adolescents should be a key objective, both in prevention and in intervention.

\section{Keywords}

Mental health · Children · Adolescents .

Protective factors $\cdot$ Risk factors

\section{Korrespondierender Autor}

\section{Dr. B.-M. Kurth}

Robert Koch-Institut, Postfach 650261, 13302 Berlin

E-Mail: KurthB@rki.de 